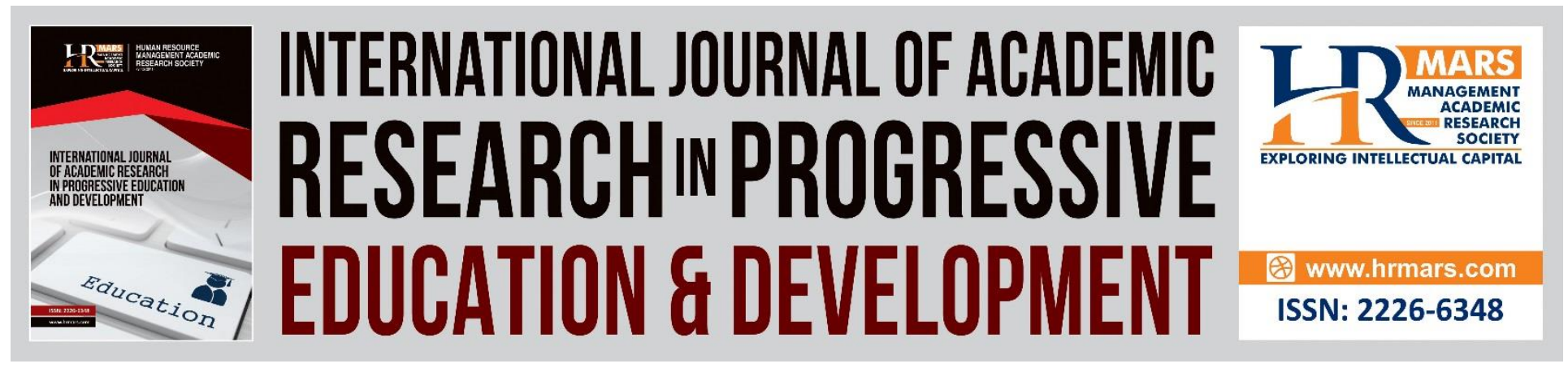

\title{
Conceptualization of Morphological Awareness and Productive Vocabulary Knowledge with Academic Writing
}

Hani Qasem Mohammed Asaad, Ahmad Affendi Shabdin

To Link this Article: http://dx.doi.org/10.6007/IJARPED/v8-i1/5271

DOI: $10.6007 /$ IJARPED/v8-i1/5271

Received: 06 Nov 2018, Revised: 29 Dec 2018, Accepted: 22 Jan 2019

Published Online: 30 Jan 2019

In-Text Citation: (Asaad \& Shabdin, 2019)

To Cite this Article: Asaad, H. Q. M., \& Shabdin, A. A. (2019). Conceptualization of Morphological Awareness and Productive Vocabulary Knowledge with Academic Writing. International Journal of Academic Research in Business and Social Sciences, 8(1), 1-11.

\section{Copyright: (C) 2019 The Author(s)}

Published by Human Resource Management Academic Research Society (www.hrmars.com)

This article is published under the Creative Commons Attribution (CC BY 4.0) license. Anyone may reproduce, distribute, translate and create derivative works of this article (for both commercial and non-commercial purposes), subject to full attribution to the original publication and authors. The full terms of this license may be seen at: http://creativecommons.org/licences/by/4.0/legalcode

Vol. 8, No. 1, 2019, Pg. 1 - 11

http://hrmars.com/index.php/pages/detail/IJARPED

Full Terms \& Conditions of access and use can be found at http://hrmars.com/index.php/pages/detail/publication-ethics 


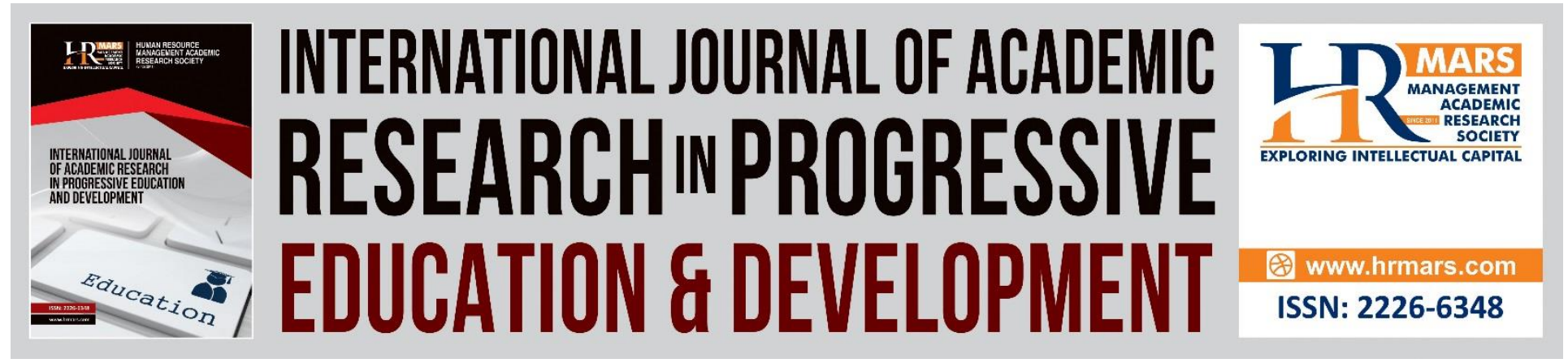

\title{
Conceptualization of Morphological Awareness and Productive Vocabulary Knowledge with Academic Writing
}

\author{
Hani Qasem Mohammed Asaad \\ Universiti Utara Malaysia, 06010 UUM, Sintok, Kedah Darul Aman, Malaysia \\ Email: hani_alasbahi@yahoo.com
}

\begin{abstract}
Ahmad Affendi Shabdin
Universiti Utara Malaysia, School of Languages, Civilisation and Philosophy, UUM College of Arts and Sciences, 06010 UUM, Sintok, Kedah Darul Aman, Malaysia

Email: affendi@uum.edu.my
\end{abstract}

\begin{abstract}
The current paper represents a conceptual framework for the relationship between morphological awareness and academic writing directly and indirectly through the mediation of productive vocabulary knowledge. Reviewing the literature guided the researcher in developing the conceptual framework of the current study. The present study suggested a strategy which may help the second language postgraduate students in enhancing their productive vocabulary knowledge regarding the size of words they know and how deep they know about them, which eventually would help the students in improving their academic writing. Moreover, the current paper addresses the relationship between morphological awareness and the different language skills conceptualised in the literature review. It also delineates the role of vocabulary knowledge and academic vocabulary to academic writing. Eventually, a conceptual framework regarding the direct relationship between morphological awareness and academic writing among the second language postgraduate students and the indirect relationship between both of them through the mediation of productive vocabulary knowledge is suggested in this current paper.

Keywords: Morphological awareness, academic writing, productive vocabulary knowledge, conceptual framework.
\end{abstract}


International Journal of Academic Research in Progressive Education and Development Vol. 8, No. 1, 2019, E-ISSN: 2226-6348 @ 2018 HRMARS

\section{Introduction}

Learning and teaching vocabulary are of great importance and considered as the central activities in the second language teaching (Al Farsi 2008). A language learner can develop a way for vocabulary learning by deploying strategies for learning. These strategies assist as conscious or unconscious learning techniques in reinforcing comprehension, learning and retention (Asgari \& Mustapha 2011; Cohen 2014; O'malley \& Chamot 1990; Wang 2018). One of the strategies for learning vocabulary is using the knowledge of morphology and being aware of the combination of morphemes to learn and create new words. Morphological awareness includes knowledge about both meaning and sounds in addition to the knowledge about rules of combining morphemes for word formation in a language (Kuo \& Anderson 2006).

Morphological awareness shows learners of English the morphemes that a complex word is composed of by using the knowledge of morphology. Accordingly, the learners become able to disassemble the complex word into its smallest meaningful parts (i.e. neighborhood is disassembled into neighbor=next door person + -hood= the state of being). Then, the learners learn the meaning of the root and affixes that the complex word contains. Eventually, the learners use those meaningful parts of the complex word to come up with a new vocabulary by reassembling these meaningful parts (brotherhood, childhood, priesthood).

Research about morphological awareness has started in the literature by investigating its relationship with L1 first grade students' reading achievements, and was considered very important compared to phonological awareness (Carlisle \& Feldman 1995). The importance of morphology increased as students advanced from one grade to another (Carlisle 2000; Carlisle \& Feldman 1995; Green et al. 2003). Phonological awareness has been contributing significantly to the early decoding children' abilities while morphological awareness has been considered increasingly significant for the upper elementary grades concerning word reading and reading comprehension (Singson, Mahony, \& Mann 2000).

Wolter and Gibson (2015) proposed that there was an influence of morphological awareness on literacy improvement in a language among students with or without language deficits and it was probably an optimum intervention focus for the development of words, vocabulary decoding, reading comprehension and vocabulary reading. Furthermore, the researchers claimed that the process of manipulating morphemes was considered as one essential language skill that influenced reading and writing as well. Awareness about morphology could help writers by providing options in constructing vocabulary required academically as these lexical forms are considered as a feature of the academic register (McCutchen \& Stull 2015).

Writing is an area of knowledge with principles in which an entire, struggling, active involvement is required (Rose 1985; Singh 2015). Academic writing, as a way of thinking, is essential for the international students' academic success in higher education (Arkoudis \& Tran 2007). For tertiary second and foreign language students, writing is believed to be rigor in which they encounter various difficulties regarding vocabulary, grammar, and syntax (Rose 1985; Singh 2015). Paltridge (2002) claimed that writing a thesis was a daunting process, particularly for L2 students because of the lack of proficiency in the English language.

Vocabulary knowledge is essential to a writer as it plays a leading role in the first and second language writing proficiency and fluency (Schoonen et al. 2003). The high quality of writing is 
likely to include a greater vocabulary diversity, vocabulary of low frequency, and sentences with more complexity (McNamara, Crossley, \& McCarthy 2009).

This study provides a suggested strategy to help L2 postgraduate students to encounter the problem of inadequate vocabulary and, eventually, to improve their academic writing by raising their morphological awareness. The role of vocabulary knowledge to writing and the relationship of morphological awareness to different language skills are mentioned in the literature review section.

\section{Literature Review}

Significance of Vocabulary to Academic Writing

It is indisputable that English has been the language used for researching and publication as well. Based on this statement, for accessing to the researches and studies related to their discipline, tertiary students require possessing a good receptive command of English. However, they need to have a good productive knowledge of academic language due to the different tasks in which they are involved for academic writing, such as dissertations, thesis, essays and assignments (Paquot 2010).

Acquiring Vocabulary is one of the most crucial research fields because of the significance of vocabulary in learning English (Zhai 2016). Vocabulary is essential for language learners for developing their language abilities and for creating meaning. Due to the significance of vocabulary for the learners' language development, learners need to increase their vocabulary and need a word-learning strategy that could help them overcome the problem of lack of vocabulary so that learners read and write successfully (Xu 2010).

Lack of vocabulary is like a barrier that stands against the learners' language development and causes difficulties for learners in succeeding in their study (Varatharajoo, Asmawi, \& Abedalaziz 2014). Lack of vocabulary among the $L 2$ students is probably attributed to their poor awareness of linguistic aspects, especially in their morphological awareness (Jalaluddin, Norsimah, \& Kesumawati 2008)

Morphology usage is one of the word-learning strategies. 'Morpheme' is defined by Carlisle (2000) as the name of meaningful parts of a word that can be used by a reader so that the meaning of an unfamiliar word is determined. Being aware of morphemes and the internal structure of words, a learner can learn new vocabulary by using this knowledge in examining the unknown words and figuring out their meanings.

The importance of morphological awareness in figuring out the meaning of unknown words was hinted by Morin (2003). She described the ability to use the word-formation knowledge as an increasingly necessary skill that could be used by the learners while being exposed to unknown vocabulary.

Bauer and Nation (1993) indicated that a second language learner could use word forms with regular affixes productively and "a word family consists of a base word and all its derived and inflected forms that can be understood by a learner without having to learn each form separately". Carlisle (2003) indicated to the role of word family in facilitating language learning instead of studying isolated complex words.

As learners of English go from one level of study to another, the difficulty of the language used in texts or expected to be used in a composition is getting more. Xu (2010) claimed that learners, while moving from one level of study to another (i.e. from primary to secondary, or from 
secondary to tertiary), had difficulties in understanding the meaning of complex vocabulary they encountered in their study.

Read (2000) described the lexical characteristics that should be included for good writing, and they are:

1- A variety of words rather than the usage of a small amount of vocabulary repeatedly. A proficient writer needs to possess plenty of words that enable him to write without repetition.

2- Low frequent words, which are proper for the style of writing and the topic of writing, are selected rather than selecting general, everyday words (lexical sophistication).

3- A relatively high percentage of lexical (content) words, in comparison with the grammatical (function) words. This feature is called 'lexical density'.

4- Some lexical errors found in a written text.

All of these features show the significance of vocabulary breadth to writing. Vocabulary breadth (size) is considered as one of the significant determinants of well-written composition, especially for second language students, and the usage of vocabulary in writing is the reflection of the writer's vocabulary breadth (Laufer \& Nation 1995). Measuring the vocabulary breadth of the learners of English and the variety of words they use in their writing helps in determining the quality of their writing (Laufer \& Nation 1995).

Therefore, this current study embodies a conceptual framework regarding the effect of morphological awareness on academic writing by improving the quality of L2 postgraduate students' academic writing in terms of increasing their vocabulary knowledge and strengthening their understanding about the meaning of the affixes and roots so that they can retrieve, manipulate and create new forms of words and express their ideas in writing.

Morphological awareness and Language Skills

Studies carried out previously with respect to the relationship between morphological awareness, and language skills revealed that morphological awareness was reliably related to reading comprehension (E.g. Baumann, Edwards, Boland, Olejnik, \& Kame'enui 2003; Carlisle \& Feldman 1995; Carlisle \& Fleming 2003; Choi 2015; Lesaux, Kieffer, Faller, \& Kelley 2010), word reading (E.g. Carlisle 2000; Carlisle \& Katz 2006; Wilson-Fowler \& Apel 2015), spelling (E.g. Deacon \& Bryant 2006; Kirk \& Gillon 2009; McCutchen \& Stull 2015) and receptive vocabulary (E.g. Khodadoust, Aliasin, \& Khosravi 2013). However, the relationship between morphological awareness and the writing skill, beyond spelling, among postgraduate college students is still unknown.

Many previous studies were focusing on the relationship between morphological awareness and reading comprehension or word reading. In a study conducted by Choi (2015), the researcher aimed to investigate how direct or indirect an awareness of L1 and L2 derivational morphology was contributing to $L 2$ reading comprehension through the vocabulary knowledge mediation. The three kinds of derivational morphological knowledge (syntactic, relational, and distributional), as categorized by Kuo and Anderson (2006), were assessed in this study by using the word segmentation task, sentence grammatical judgment task, and the word production task respectively. Two tests were used to assess the vocabulary knowledge among the Korean respondents: the Vocabulary Levels Test, adopted from Nation (1990), for measuring vocabulary size and the Read's Word Associates Test to assess the vocabulary depth knowledge of the Korean students. Finally, the L2 reading comprehension was examined by conducting a multiple- 
choice reading comprehension test. The study revealed that both the $\mathrm{L} 2$ derivational morphological awareness and vocabulary knowledge were directly contributing to the L2 reading comprehension. Another finding was that there was an indirect influence of the L1 derivational morphological awareness on the $L 2$ reading comprehension via the $L 2$ derivational morphological awareness.

Zhang (2016) aimed to examine the relationship between morphological awareness and reading comprehension. The morpheme recognition task, morpheme discrimination task, and reading ability test were used in the study. The findings of this study showed that morphological awareness was significantly related to reading comprehension and impacted the learners' reading comprehension performance. It showed also the mediation of lexical inferences between morphological awareness and reading comprehension. Levesque, Kieffer, and Deacon (2017) conducted a study with the purpose of examining the contribution of morphological awareness to reading comprehension. The study revealed that morphological awareness had a moderate effect on reading comprehension.

By going through the literature, it has been revealed the contribution of morphological awareness to early literacy development, especially for children by investigating the relationship of morphological awareness to both reading and spelling (Carlisle 1988, 2000; Carlisle \& Feldman 1995; Carlisle \& Katz 2006; Deacon \& Bryant 2006; Green et al. 2003; Singson et al. 2000). It serves both skills by providing learners of English a tool by which they can separate words into smaller parts so that they can read and spell long and complex words. Learners can use this knowledge of morphology to understand the meaning of each part of a word and come up with its definition (Carlisle 2000).

It has been shown in the literature that morphological awareness has a relationship with word reading (Carlisle 2000; Carlisle \& Stone 2005; Singson et al. 2000). As children progress in their learning, the complexity of the texts they face in their reading increases. Children in the elementary level face vocabularies that are longer, morphologically complex, of low frequency and are not used in their oral language (Green et al. 2003). To encounter this challenge, the children tended to increase their vocabulary by the use of morphological affixes and known base words for obtaining the meaning of unfamiliar words (Anglin, Miller, \& Wakefield 1993).

The relationship between morphological awareness and spelling has been investigated in some previous studies. Deacon and Bryant (2006) confirmed the role of morphological awareness as an effective spelling strategy. Nagy et al. (2006) found out that morphological awareness contributed significantly to spelling among children (4th graders - 9th graders). McCutchen and Stull (2015) came up with the conclusion that morphological awareness had assisted the USA children' spelling during their writings. The contribution of morphological awareness to academic writing is still unknown. Therefore, this current study embodies a conceptual framework for the relationship between morphological awareness and academic writing.

\section{Conceptual Framework}

The literature about morphological awareness and the previous studies conducted in relation to morphological awareness were reviewed previously in this study, which might assist the researcher in developing the conceptual framework for the current study and in understanding the relationship between morphological awareness and academic writing. Figure 1 shows the conceptual framework proposed to investigate the relationship between the variables of the 
present study. It shows the conceptualized relationship between the independent variable (morphological awareness) and the dependent variable (academic writing) by training the second language postgraduate students in a morphological awareness intervention.

Based on the conceptual framework, the second language postgraduate students will be trained in a morphological awareness intervention in order to raise their morphological awareness. Productive vocabulary knowledge is involved in this study as a mediator. The researcher proposed that morphological awareness would contribute directly to academic writing and indirectly to it through productive vocabulary knowledge. It is proposed that increasing the L2 postgraduate students' morphological awareness would increase the size and the quality of their English vocabulary used by them in writing regarding using a variety of words and using more low-frequency words to improve and enhance the quality of their academic writing.

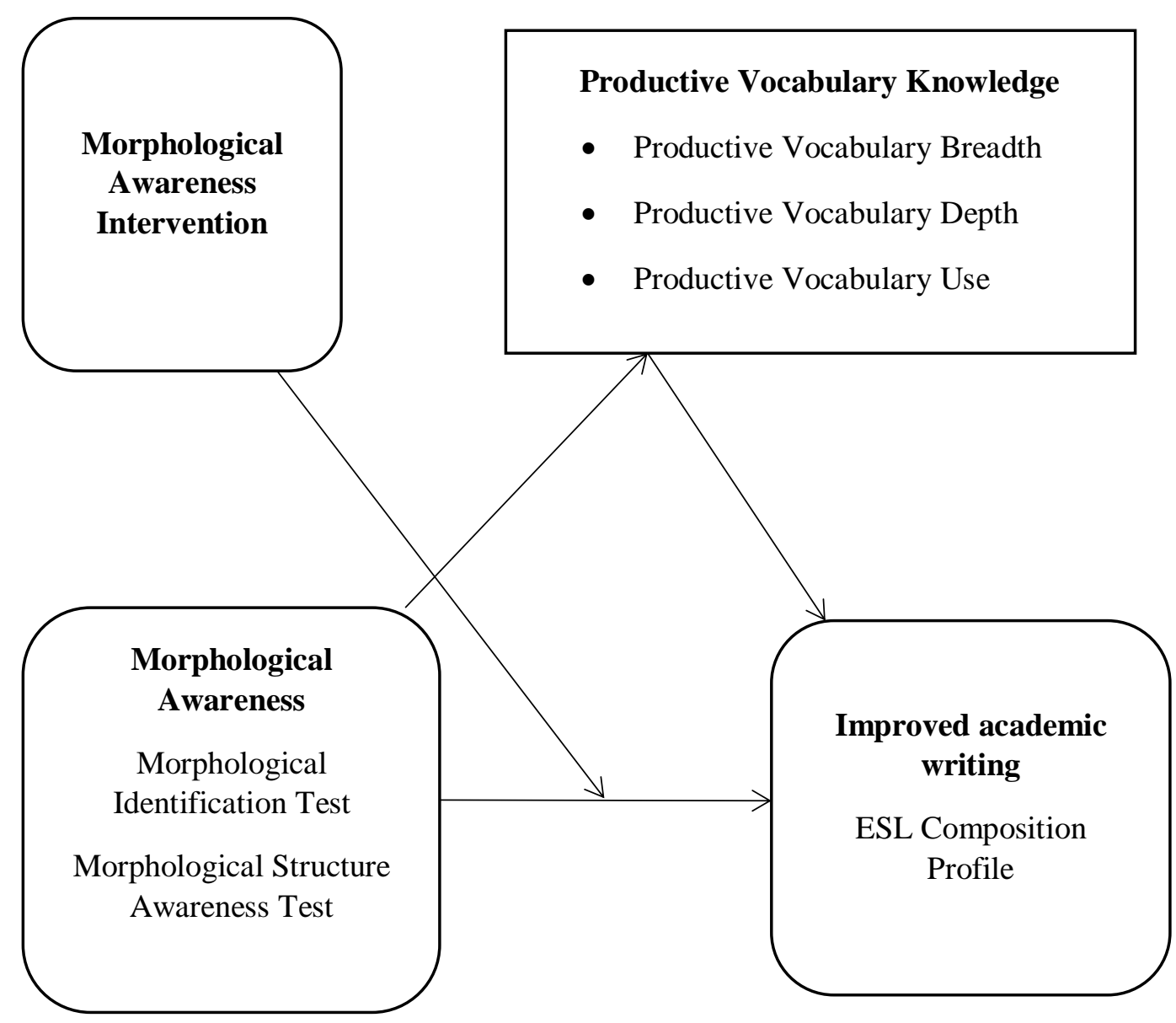

Figure1. Conceptual Framework 
International Journal of Academic Research in Progressive Education and Development Vol. 8, No. 1, 2019, E-ISSN: $2226-6348$ @ 2018 HRMARS

\section{Implications of the Study}

The implications of the current study can be pointed out and described in terms of its possible usefulness and importance as a guideline for practical English language learning and teaching, curriculum designing and material development, and empirical researchers.

This present study may provide an insight to guide both L2 postgraduate students and teachers of English language by shedding light on the importance of being aware of morphology and what benefits they both can gain in enhancing the students' academic writing performance; and suggesting a strategy that may enable the postgraduate students to increase the size of their productive vocabulary knowledge. Morphological awareness is a possible way of independent learning in which $L 2$ postgraduate students would be able to use and strengthen their vocabulary knowledge and reduce the morphologically related errors made while writing. Consequently, their academic writing performance would become better eventually. They may also help them in realizing how much vocabulary and what type of vocabulary they know so that they become aware of what kind of vocabulary they should be putting more focus on to improve their learning outcomes, especially academic writing.

The conceptual framework proposed in this current study may have implications for teachers of English language as it draws the teachers' attention to the importance of putting more focus on teaching morphology and the different forms of words and urging their students to use various forms of words in their writings. The current study may have implications by making curriculum developers consider including morphology courses in the teaching methods or while designing a curriculum. This study may also draw the English language material developers to the significance of teaching morphology and allot more word formation and morphology-related lessons.

At last, based on the literature review and to the best knowledge of the researcher, there is lack of empirical studies concerning investigating the relationship between morphological awareness and academic writing. Another theoretical gap can be tested in future empirical studies, which is the effect of morphological awareness intervention in raising the L2 postgraduate students' morphological awareness and improving their academic writing.

\section{Conclusion}

This paper presents a conceptual framework concerning the relationship of morphological awareness with academic writing. The conceptual framework of this study includes the productive vocabulary knowledge as mediator in this relationship. On the basis of the previous studies related to morphological awareness, this present study is an attempt to fill theoretical gaps as there is lack of studies investigating the relationship between morphological awareness and academic writing among the L2 postgraduate students in addition to the mediation role of productive vocabulary knowledge in this relationship. Moreover, this conceptual paper proposes that there is an effect of morphological awareness intervention on the $L 2$ postgraduate students on the performance of morphological awareness and productive vocabulary knowledge and, consequently, may affect the L2 postgraduate students' academic writing performance.

The present study describes the role of productive knowledge to academic writing and how morphological awareness can contribute to increase the students' productive vocabulary knowledge and improve their academic writing accordingly. Testing the proposed conceptual framework in empirical studies will be required to confirm the relationship and make it more 
meaningful to add to the body of knowledge concerning the contribution of morphological awareness to English language skills.

\section{References}

Al Farsi, B. (2008). Morphological awareness and its relationship to vocabulary knowledge and morphological complexity among Omani EFL University students.

Anglin, J. M., Miller, G. A., \& Wakefield, P. C. (1993). Vocabulary development: A morphological analysis. Monographs of the society for research in child development, 58(10), i-186.

Arkoudis, S., \& Tran, L. T. (2007). International students in Australia: Read ten thousand volumes of books and walk ten thousand miles. Asia Pacific Journal of Education, 27(2), 157-169.

Asgari, A., \& Mustapha, G. B. (2011). The type of vocabulary learning strategies used by ESL students in university Putra Malaysia. English language teaching, 4(2), 84-90.

Bauer, L., \& Nation, P. (1993). Word families. International journal of Lexicography, 6(4), 253-279.

Baumann, J. F., Edwards, E. C., Boland, E. M., Olejnik, S., \& Kame'enui, E. J. (2003). Vocabulary tricks: Effects of instruction in morphology and context on fifth-grade students' ability to derive and infer word meanings. American Educational Research Journal, 40(2), 447-494.

Carlisle, J. F. (1988). Knowledge of derivational morphology and spelling ability in fourth, sixth, and eighth graders. Applied psycholinguistics, 9(03), 247-266.

Carlisle, J. F. (2000). Awareness of the structure and meaning of morphologically complex words: Impact on reading. Reading and writing, 12(3), 169-190.

Carlisle, J. F., \& Feldman, L. (1995). Morphological awareness and early reading achievement. Morphological aspects of language processing, 189-209.

Carlisle, J. F., \& Fleming, J. (2003). Lexical processing of morphologically complex words in the elementary years. Scientific Studies of Reading, 7(3), 239-253.

Carlisle, J. F., \& Katz, L. A. (2006). Effects of word and morpheme familiarity on reading of derived words. Reading and writing, 19(7), 669-693.

Carlisle, J. F., \& Stone, C. (2005). Exploring the role of morphemes in word reading. Reading research quarterly, 40(4), 428-449.

Choi, Y. H. (2015). Roles of L1 and L2 derivational morphological awareness in $L 2$ reading through the mediation of L2 vocabulary knowledge. The Journal of Asia TEFL, 12(3), 81-114.

Cohen, A. D. (2014). Strategies in learning and using a second language: Routledge.

Deacon, S. H., \& Bryant, P. (2006). This turnip's not for turning: Children's morphological awareness and their use of root morphemes in spelling. British journal of developmental psychology, 24(3), 567-575.

Green, L., McCutchen, D., Schwiebert, C., Quinlan, T., Eva-Wood, A., \& Juelis, J. (2003). Morphological development in children's writing. Journal of Educational Psychology, 95(4), 752-761.

Jalaluddin, N. H., Norsimah, M., \& Kesumawati, A. (2008). The mastery of English language among lower secondary school students in Malaysia: A linguistic analysis. European Journal of Social Sciences, 7(2), 106-119.

Khodadoust, E., Aliasin, S., \& Khosravi, R. (2013). The Relationship between morphological awareness and receptive vocabulary knowledge of Iranian EFL learners. . International Journal of Educational Research and Technology, 4(1), 60-67. 
Kirk, C., \& Gillon, G. T. (2009). Integrated morphological awareness intervention as a tool for improving literacy. Language, speech, and hearing services in schools, 40(3), 341-351.

Kuo, L.-j., \& Anderson, R. C. (2006). Morphological awareness and learning to read: A crosslanguage perspective. Educational Psychologist, 41(3), 161-180.

Laufer, B., \& Nation, P. (1995). Vocabulary size and use: Lexical richness in L2 written production. Applied Linguistics, 16(3), 307-322.

Lesaux, N. K., Kieffer, M. J., Faller, S. E., \& Kelley, J. G. (2010). The effectiveness and ease of implementation of an academic vocabulary intervention for linguistically diverse students in urban middle schools. Reading research quarterly, 45(2), 196-228.

Levesque, K. C., Kieffer, M. J., \& Deacon, S. H. (2017). Morphological awareness and reading comprehension: Examining mediating factors. Journal of experimental child psychology, $160,1-20$.

McCutchen, D., \& Stull, S. (2015). Morphological awareness and children's writing: accuracy, error, and invention. Reading and writing, 28(2), 271-289.

McNamara, D. S., Crossley, S. A., \& McCarthy, P. M. (2009). Linguistic features of writing quality. Written Communication, 27(1), 57-86.

Morin, R. (2003). Derivational morphological analysis as a strategy for vocabulary acquisition in Spanish. Modern Language Journal, 200-221.

O'malley, J. M., \& Chamot, A. U. (1990). Learning strategies in second language acquisition: Cambridge university press.

Paltridge, B. (2002). Thesis and dissertation writing: an examination of published advice and actual practice. English for Specific Purposes, 21(2), 125-143.

Paquot, M. (2010). Academic vocabulary in learner writing: From extraction to analysis: Bloomsbury Publishing.

Read, J. (2000). Assessing vocabulary: Cambridge University Press.

Rose, M. (1985). The language of exclusion: Writing instruction at the university. College English, 47(4), 341-359.

Schoonen, R., Gelderen, A. v., Glopper, K. d., Hulstijn, J., Simis, A., Snellings, P., \& Stevenson, M. (2003). First language and second language writing: The role of linguistic knowledge, speed of processing, and metacognitive knowledge. Language learning, 53(1), 165-202.

Singh, M. K. M. (2015). International graduate students' academic writing practices in Malaysia: Challenges and solutions. Journal of International Students, 5(1), 12-22.

Singson, M., Mahony, D., \& Mann, V. (2000). The relation between reading ability and morphological skills: Evidence from derivational suffixes. Reading and writing, 12(3), 219252.

Varatharajoo, C., Asmawi, A. B., \& Abedalaziz, N. A. M. (2014). Measuring morphological knowledge among secondary school students: Implications for effective vocabulary acquisition. Malaysian Journal of Languages and Linguistics, 3(1), 129-138.

Wang, I. K.-H. (2018). Learning Vocabulary Strategically in a Study-Abroad Context Learning Vocabulary Strategically in a Study Abroad Context (pp. 231-268): Springer.

Wilson-Fowler, E. B., \& Apel, K. (2015). Influence of morphological awareness on college students' literacy skills a path analytic approach. Journal of Literacy Research, 1-28.

Wolter, J. A., \& Gibson, F. E. (2015). Morphological awareness assessment and intervention to improve language and literacy. Paper presented at the Seminars in speech and language. 
International Journal of Academic Research in Progressive Education and Development Vol. 8, No. 1, 2019, E-ISSN: 2226-6348 (c) 2018 HRMARS

Xu, S. H. (2010). Teaching English language learners: Literacy strategies and resources for K-6: Guilford Press.

Zhai, L. (2016). A Study on Chinese EFL learners' vocabulary usage in writing. Journal of Language Teaching and Research, 7(4), 752-759.

Zhang, H. (2016). Concurrent and longitudinal effects of morphological awareness on reading comprehension among Chinese-speaking children. Reading Psychology, 37(6), 867-884. 